\section{Individual's Resistance Regarding BPM Initiative: Case Study of the Insurance Company}

\author{
Mirjana Pejić Bach \\ University of Zagreb, Faculty of Economics \& Business, Croatia \\ mpejic@efzg.hr \\ Vesna Bosilj Vukšić \\ University of Zagreb, Faculty of Economics \& Business, Croatia \\ vbosilj@efzg.hr \\ Dalia Suša Vugec \\ University of Zagreb, Faculty of Economics \& Business, Croatia \\ dsusa@efzg.hr
}

\begin{abstract}
Though the individual's resistance is very often considered a significant barrier to BPM success, the literature on that topic is quite scarce. With the aim to shed light on this topic, we have conducted research of a Croatian insurance company. We examined the impact of individual's resistance regarding BPM initiative using the theory of reasoned action. Structural equation model was developed using the data collected by the survey among company employees. The results indicate that subjective norms are positively related to the individual's resistance regarding BPM initiative, while positive initial belief regarding BPM initiative tends to decrease the probability of resistance to change.
\end{abstract}

Keywords: business process management, theory of reasoned action, individual's resistance, insurance company, change management, Croatia

\section{Introduction}

Business process management (BPM) has been of a great interest in many companies for more than two decades because of its potential to significantly increase efficiency and to improve decision making on both operational and tactical levels. For industries, such as finance and insurance, the main goal of BPM is to gain a competitive advantage by shortening the roll-out time for new products and services. BPM aims to improve business processes by modeling and analyzing them, but it also has a broader scope: from process automation and monitoring to performance and operations management and the organization of work (van der Aalst, 2013; Milanovic Glavan, 2011).

Nowadays, companies in service industries (e.g. banks, insurance companies and telecommunications) that facilitate transactions within a network of customers put much effort into standardizing services and implementing process performance measurement systems (Fjeldstad and Ketels, 2006; Harmon et al., 2006). Since companies from the finance and insurance sectors have very complicated processes
ORIGINAL SCIENTIFIC PAPER

RECEIVED: JUNE 2017

REVISED: AUGUST 2017

ACCEPTED: AUGUST 2017

DOI: 10.1515/ngoe-2017-0021

UDK: $368.021: 658$

JEL: M15

Citation: Pejić Bach, M., Bosilj Vukšić, V., \& Suša Vugec, D. (2017). Individual's Resistance Regarding BPM Initiative: Case Study of the Insurance Company. Naše gospodarstvo/Our Economy, 63(4), 29-39. DOI: 10.1515/ngoe-2017-0021

\section{NG OE}

NAŠE GOSPODARSTVO OUR ECONOMY

\section{Vol. 63 No.4 2017}

pp. $29-39$ 
that are constrained by special procedures, business rules, and laws, BPM provides a significant helps in the process of documentation and standardization (McIvor et al., 2009). According to Francischini and Mello (2010), "the insurance industry has been identified as a leading adopter of BPM". The findings of their research show that cost and time reduction of process execution, the transformation of unstructured processes into routinized transactions, and increased productivity were the highest ranked BPM benefits in six Brazilian banks (Francischini and Mello, 2010).

A number of authors agree about the holistic nature of BPM concept (Van Looy et al. 2014; Buh et al. 2015, Trkman 2010). Besides, Kettenbohrer et al. (2015) and van der Aalst (2013) emphasize that much attention should be given to human factors and management support. According to Goksoy et al. (2012) "human participation is of the essence for BPM project success” while "people and organizational cultures are identified as the main obstacles related to BPM implementation” (Aparecida et al., 2012).

Since the findings of a survey conducted by Bosilj Vuksic et al. (2013) showed that "Croatian service industry firms do not use the potential of BPM in performance management to a satisfactory level," the aim of this research is to shed light on the factors of employees' resistance regarding a BPM initiative in one Croatian insurance company.

The paper is structured in three parts. First, a theoretical framework is presented: culture and people as critical success factors of BPM initiatives are discussed; the factors of individual's resistance toward changes related to BPM implementation are identified and elaborated. Next, the methodology of the research is described and the research model is developed using Theory of Reasoned Actions (TRA). Finally, research methodology is described, the results of empirical research are analyzed and the final conclusions are given.

\section{Culture and People as Core Elements of BPM}

Many authors agree that the final outcome of BPM projects is determined "by the combination of soft and hard factors" (Hanafizadeh and Osouli, 2011; Trkman 2010). De Bruin and Doebeli (2009) define organizational culture and people's involvement as the soft factors leading to a successful change. The soft side of BPM is concerned with relationships and interactions among people and their behaviors, mindsets, and skills. The term "people" in the context of BPM is related to "the individuals and groups who continually enhance, practice and implement their process-related knowledge” (de Bruin and Doebeli, 2009, p. 8). According to Kettenbohrer (2016), this can be used as a generic term since it also comprises the keywords "staff” or "employee." Organizational culture represents values, beliefs, attitudes and behaviors of the employees and reflects their behavior (Hofstede, 1993; Schein, 1990).

Cameron and Quinn (2006) identify 4 types of organizational culture: clan, adhocracy, market and hierarchy culture. Previous research revealed that organizational culture has a strong impact on BPM implementation success (Ahmad and Zairi, 2007; Alibabaei et al., 2010), while other studies specified adhocracy culture and clan culture to be appropriate for adopting BPM (Hribar and Mendling, 2014; Buh, 2016). Besides, Schmiedel et al. (2013) identified 4 BPM supportive cultural values: customer orientation, excellence, responsibility, and teamwork. According to the authors, these values are considered to be the facilitators of successful BPM.

Though the organizational culture unites common values and beliefs of organization employees, the perception on BPM, its usefulness and willingness to adopt BPM, varies between organizational sub-groups and individuals. Some authors recognize a "work- group culture” as an important factor influencing BPM and provide evidence that this dimension of BPM is still widely under-researched (Schmiedel et al., 2013; vom Brocke and Sinnl, 2011; Pritchard and Armistead, 1999). The term "work group culture" refers to cultures of sub-groups (departments, process groups, and teams) in organizations (vom Brocke and Sinnl, 2011).

According to Rosemann and vom Brocke (2010), the organizations "need to develop the capabilities to assure the employees’ BPM readiness and commitment.” At the same time, the researchers should intensify the efforts "to extend the knowledge in human and cultural aspect of BPM" (Hanafizedah and Osouli, 2011). Summarizing the literature review findings, Kettenbohrer (2016) explains the relation of culture and people in BPM in the following way. In the first phase, top management initiative toward BPM introduces changes in process flows and organizational structure. In the second phase, the new working environment triggers changes in employees' attitudes and actions, which consequently influences the organizational culture.

\section{Understanding the Factors of Individual's Resistance regarding BPM Initiative}

Vom Brocke et al. (2014), and Tumbas and Schmiedel (2013) emphasize the importance of process users' involvement and motivation for BPM success. Kettenbohrer (2016) conducted a research to examine articles dealing with people in BPM. The results of the content-based analysis showed 
that "three key concepts which dominate the BPM literature regarding people are: expertise, empowerment, and commitment” (Kettenbohrer, 2016). Similarly, Hanafizadeh and Osouli (2011) derived six factors leading to a successful change: (1) revision of motivation and reward systems; (2) communication systems; (3) empowerment; (4) people involvement; (5) training and education and (6) organizational culture. The readiness of people to accept, promote and implement change is a very important driver of BPM initiatives. Sikdar and Payyazhi (2014) recognized that "empowering employees, promoting trust, creating a critical mass at the operational level through engaging them proactively in BPM project could help organizations to avoid or minimize the resistance to business process change initiatives".

Besides positive factors related to human resources, the authors also investigate the negative factors regarding BPM that are: "(1) lack of understanding of BPM implementation; (2) insufficient training and lack of knowledge to implement BPM; (3) company culture not ready for BPM initiative; (4) individuals' negative perception about the ease of use and usefulness of BPM and (5) poor and inadequate communication and participation of users within a BPM project”' (Tennat and Wu, 2005; de Bruin and Doebeli, 2009). Therefore, several factors that could trigger the resistance to change at the individual level are recognized, such as the fear of job loss because of redesigned processes, dissatisfaction with the logic of decision-making, conflicts and lack of communication and interaction within the new working environment. Skepticism about project result and authority loss are mentioned by Abdolvand et al. (2008) and Palmer (2004) as the most common factors influencing individuals' BPM rejection. The ineffective or unethical change of management practices and biased managerial sense-making can result in resistance to change (Ford et al., 2008).

A number of authors used different social psychological models and theories to analyze factors that influence individual behavior regarding the adoption of the information technology. Theory of Reasoned Actions (TRA), Technology Acceptance Model, and similar theories (e.g. Theory of Planned Behaviour, Diffusion of Innovations and Unified Theory of Acceptance and Use of Technology) were developed to examine individuals' beliefs, attitudes, and norms in

Table 1. TRA factors and resistance to BPM change: definitions and issues

\begin{tabular}{|c|c|c|}
\hline TRA determinant: definition & Issues & Source \\
\hline \multirow{3}{*}{$\begin{array}{l}\text { Initial beliefs (IB): the reflection of } \\
\text { the individual's salient behavioral } \\
\text { beliefs toward change (Bosilj Vuksic } \\
\text { et al., 2017). }\end{array}$} & $\begin{array}{l}\text { Understanding the need for change: the change is not } \\
\text { needed; the change is not realistic. }\end{array}$ & Decker et al., 2012 \\
\hline & $\begin{array}{l}\text { Feelings and expectations: low motivation to change; weak } \\
\text { Buy-in, low morale. }\end{array}$ & Decker et al., 2012 \\
\hline & $\begin{array}{l}\text { Assessment of a new work environment; hard work expected; } \\
\text { too much change coming; a lot of effort required. }\end{array}$ & $\begin{array}{l}\text { Decker and McCormack, } \\
2008\end{array}$ \\
\hline \multirow{2}{*}{$\begin{array}{l}\text { Individual's commitment toward } \\
\text { organization (OC): the intention } \\
\text { of an individual to participate in } \\
\text { changes within the organization } \\
\text { (Bosilj Vuksic et al., 2017). }\end{array}$} & $\begin{array}{l}\text { Low commitment: employee's needs are not met; no desire } \\
\text { to stay in the organization; no job satisfaction; lack of } \\
\text { establishment of common goals, low emotional commitment. }\end{array}$ & $\begin{array}{l}\text { Wong et al., 2005; Faisal } \\
\text { and Al-Esmael, 2014; } \\
\text { Aprecaida et al., } 2012 \text {. }\end{array}$ \\
\hline & $\begin{array}{l}\text { Loyalty: acceptance of organizational changes; eagerness to } \\
\text { work hard for the organization; low turnover intentions, job } \\
\text { security; "current organization is considered to be the best } \\
\text { of all organizations"; strong belief in organization's values, } \\
\text { desire to achieve organization's goals. }\end{array}$ & Faisal and Al-Esmael, 2014 \\
\hline
\end{tabular}

Subjective norms $(\mathrm{SN})$ : reflecting the relevance of reference groups (colleagues, managers or subordinates) for individual behavior within BPM initiative (Bosilj Vuksic et al., 2017).

Resistance to BPM change: definition Issues

Resistance to change (RES): individual (active or passive) response to changes driven by BPM initiative (Bosilj Vuksic et al., 2017).
Employees fear job loss

Feeling uncomfortable with new working environment:

Social pressure to perform or not to perform changes: the individual's impression that most people who are important to him or who influence his opinion think he should or should not perform a specific behavior expressing negative feelings and thoughts about the change declining new positions and roles

Involvement in decision-making and communication process: refusing to engage the system, discarding new procedures and communication channels
Fishbein and Ajzen, 1975;

Eikebrokk et al., 2011

Source

Abdolvand et al., 2008

Abdolvand et al., 2008, Laumer and Eckhardt, 2010

Al-Mashari and Zairi, 2000; Laumer et al., 2010

Al-Mashari and Zairi, 2000; Laumer et al., 2010

Source: Bosilj Vuksic et al., 2017 
relation to technology adoption. Recker (2010) concluded that theories from the field of IT and IS adoption can be used for determining BPM acceptance or resistance factors.

According to TRA, the intention of individuals to perform a certain behavior is influenced by their beliefs about the outcomes of carrying out this specific behavior (Fishbein and Ajzen, 1975). TRA hypothesizes that individual's behavior is influenced by the individual's antecedent attitude (ATT) and the subjective norm (SN) (Laumer et al., 2010). Fishbein and Ajzen (1975) defined two psychological variables as follows:

- “ATT is the individual's positive or negative feeling about performing a behavior that is influenced by: (1) initial beliefs and feelings regarding the consequences arising from individual's behavior and (2) evaluation of the advantages or disadvantages of those consequences.

- $\mathrm{SN}$ is the individual's perception of what important others think the individual should do. In comparison to $\mathrm{SN}$, the term "social norm" is much wider since it comprises a broad range of permissible, but not necessarily expected or desired behaviors”.

Based on the preliminary literature review and following the idea of TRA, this study seeks to understand whether ATT and SN are related to the resistance to change (RES), thus influencing BPM success. Table 1 contextualizes the factors (ATT and SN) influencing resistance to BPM change (Bosilj Vuksic et al., 2017). For the purpose of this research, the ATT issues are categorized into two groups: initial beliefs (IB) and individual's commitment toward organization (OC). Since the human dimension of organizational change includes organizational commitment (OC) at the individual level, this factor is added in TRA as a sub-group of ATT. OC is related to the behaviors of employees and their identification with a particular organization. The strength of individual's attachment to the organization depends on its evaluation of behavior consequences. It is associated with the mindset that ties people to the organization and enhances their participation and involvement in changes (Meyer et al. 2012; Kuo, 2013).

Based on the literature overview, the conceptual research model is developed (Figure 1). The research model is made up of three TRA constructs: IB, OC, and SN. As a result of the previous findings, the following hypotheses are defined:

H1: Subjective norm reflecting the negative attitudes of reference groups (colleagues, managers or subordinates) toward changes within BPM increases the Resistance to change.

H2: Initial negative beliefs about the BPM increase the Resistance to change
H3: Low individual commitment toward organization increases the Resistance to change.

Figure 1. Research model

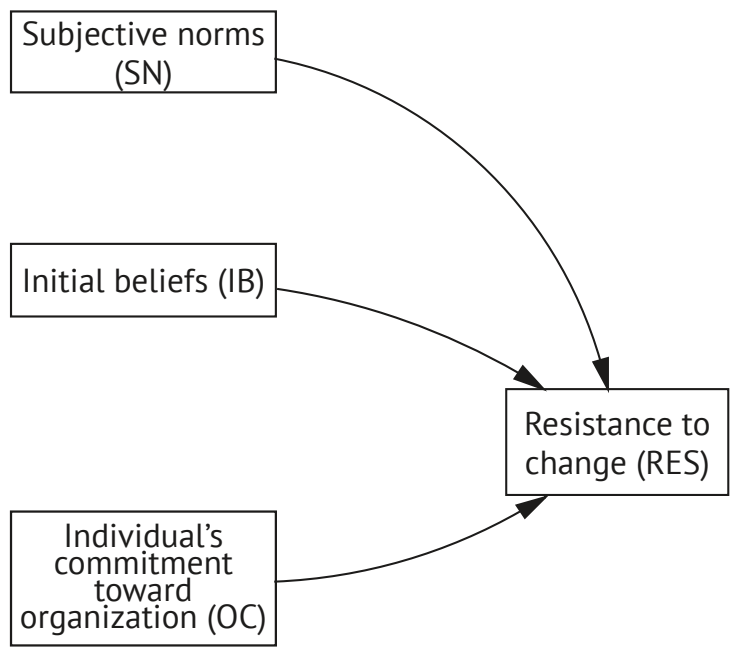

Source: Authors’ work

\section{Research Methodology}

The organization in which a survey is conducted is an insurance company in Croatia, named "Company I" for anonymity. This company has more than 1000 employees and about 50 million EUR of turnover. It is considered an early BPM adopter since the first BPM initiative was started almost two decades ago. Nowadays, all business processes are modeled and documented, process roles and positions are established, process key performance indicators (KPIs) and metrics are defined for each process, while process targets are focused on achieving customers' values and requirements.

\section{Research design and data collection}

Our research model (Figure 1) and a list of statements presented in Table 1 are operationalized into a research survey instrument. According to the research design approach suggested by de Vaus (2001) and Haynes et al. (1995), the research instrument is tested on a sample of 5 respondents, and content validity is evaluated. The number of respondents in the pilot testing of the questionnaire was selected based on the similar research that also used this approach on a smaller number of respondents, such as Lin et al. (2005) who used 3 respondents, and Lin (2007) who used 5 respondents. Table 2 presents the final version of the research instrument, which consists of 3 constructs: Subjective norms, Individual's commitment toward the organization, and Resistance to 
Table 2. Research instrument

\begin{tabular}{|c|c|c|}
\hline Construct & Code & Indicators \\
\hline \multirow{3}{*}{$\begin{array}{l}\text { SN - Subjective } \\
\text { norms (Bosilj Vuksic } \\
\text { et al., 2017) }\end{array}$} & SN1 & People who influence my behavior think that I should actively participate in BPM initiative. \\
\hline & SN2 & People who are important to me think that I should actively participate in BPM initiative. \\
\hline & IB1 & Due to BPM I would accomplish tasks more quickly. \\
\hline \multirow{3}{*}{$\begin{array}{l}\text { IB - Initial beliefs } \\
\text { (Bosilj Vuksic et al., } \\
\text { 2017) }\end{array}$} & IB2 & BPM could help improve the quality of my work. \\
\hline & IB3 & BPM would give me greater control over my work. \\
\hline & IB4 & BPM could enhance my effectiveness in my work. \\
\hline \multirow{4}{*}{$\begin{array}{l}\text { OC - Individual's } \\
\text { commitment } \\
\text { toward } \\
\text { organization (Bosilj } \\
\text { Vuksic et al., 2017) }\end{array}$} & $\mathrm{OC3}$ & I feel very little loyalty to this organization. \\
\hline & $\underline{\text { OC9 }}$ & It would take very little change in my present circumstances to cause me to leave this organization. \\
\hline & OC11 & There's not too much to be gained by sticking with this organization indefinitely. \\
\hline & OC15 & Deciding to work for this organization was a definite mistake on my part. \\
\hline \multirow{4}{*}{$\begin{array}{l}\text { RES - Resistance } \\
\text { to change (Bosilj } \\
\text { Vuksic et al., 2017) }\end{array}$} & RES1 & I don't want BPM to change the way I do my job. \\
\hline & RES2 & I don't want BPM to change the way I interact with other people in my job. \\
\hline & RES3 & I don't want BPM to change the way I make decisions in my job. \\
\hline & RES4 & I don't want BPM to change the way I share documents on my job. \\
\hline
\end{tabular}

Source: Bosilj Vuksic et al., 2017

change. Subjective norms consist of 2 items that are based on the approach used in a number of similar studies, such as Chiou (1998) and Zhou et al. (2014). During April and May 2015, the invitation was sent to 330 business experts to fill in the online survey. Business experts were from various positions in the company (including managers, process owners, and other employees), and had at least 5 years of work experience. They were asked to express their degree of

Table 3. Rotated factor matrix for four factors

\begin{tabular}{|c|c|c|c|c|}
\hline & & & & \\
\hline & 1 & 2 & 3 & 4 \\
\hline SN1 & & & & 0.945 \\
\hline SN2 & & & & 0.938 \\
\hline IB1 & 0.851 & & & \\
\hline IB2 & 0.809 & & & \\
\hline IB3 & 0.868 & & & \\
\hline IB4 & 0.874 & & & \\
\hline OC3 & & & 0.708 & \\
\hline OC9 & & & 0.698 & \\
\hline OC11 & & & 0.620 & \\
\hline OC15 & & & 0.671 & \\
\hline RES1 & & 0.663 & & \\
\hline RES2 & & 0.898 & & \\
\hline RES3 & & 0.884 & & \\
\hline RES4 & & 0.836 & & \\
\hline
\end{tabular}

Source: Authors' calculations. agreement with the suggested statements on the seven-point Likert scale from 1 (strongly disagree) to 7 (strongly agree). A total of 93 survey responses were received, yielding a 28.2 \% response rate. Further, 2 responses were discarded due to the lack of data, so the remaining 91 were accepted as reliable answers.

\section{Validity of measurement and statistical methods}

In order to uncover the underlying structure of a relatively large set of variables (Hair et al., 2006), explanatory factor analysis was conducted. Convergent validity was tested using statistical package SAS. Table 3 presents the factor analysis results for four factors. Discriminate validity was tested using the moderate approach proposed by Costello and Osborne (2005) who recommended "using loading cut-off value in the magnitude from 0.40 to 0.70 .” The results showed that all the measurement items from the questionnaire were valid for further analysis.

Next, as it was suggested by de Vaus (2001), the discriminate validity was checked using confirmatory factor analysis. The main purpose of this test was to explore whether the collected data fit a hypothesized measurement model. The results (Table 4) showed that all t-values were statistically significant at the level of 0.01 . This was in line with the Costello and Osborne (2005) approach, who said that "all $\lambda$ 's should be higher than the cut-off value of 0.50 and all of the t-values should exceed 1.96”. Hence, it was concluded that the observed loading paths were relevant. 
Further, Cronbach's alpha method was used to test the reliability of measurement instrument. As can be seen (Table 4), all Cronbach's alpha coefficients were above 0.70 , suggesting the adequate internal consistency reliability (Feldt and Kim, 2008).

In order to test the research model, structural equation modeling (SEM) was used. SEM is a multivariate statistical

Table 4. Standardized loading estimates and t-values

\begin{tabular}{lccc} 
Item & $\begin{array}{c}\text { Standardized } \\
\text { factor loading }\end{array}$ & t-values & Cronbach's alpha \\
\hline SN1 & 4.917 & 9.297 & 0.957 \\
\hline SN2 & 3.785 & 10.182 & \\
\hline IB1 & 1.009 & 9.686 & \\
\hline IB2 & 4.748 & 9.020 & 0.912 \\
\hline IB3 & 2.980 & 10.506 & \\
\hline IB4 & 3.441 & 11.091 & \\
\hline OC3 & 3.298 & 8.835 & \\
\hline OC9 & 2.174 & 7.116 & 0.737 \\
\hline OC11 & 2.253 & 7.945 & \\
\hline OC15 & 1.685 & 7.119 & \\
\hline RES1 & 1.468 & 5.874 & \\
\hline RES2 & 1.411 & 7.862 & 0.895 \\
\hline RES3 & 1.843 & 8.686 & \\
\hline RES4 & 1.974 & 7.839 & \\
\hline SOICE A & &
\end{tabular}

Source: Authors' calculations. method which is often utilized in scientific research for investigating structural relationships. SEM is a mixture of factor analysis and multiple regression analysis. In our research, multiple regression analysis was not used because it would have prevented us from testing the impact of latent constructs, which we identified by the factor analysis (Table 3).

\section{Results and Analysis}

Based on the previous positive validity test, a non-parametric correlation analysis was conducted in order to deepen the insight of our research. According to the results (Table 5), all correlations between items examined were statistically significant at the level of 0.01 . The highest correlation coefficient values between individual items were as follows: SN1 and SN2 $(\rho=0.918, p<0.01)$; IB4 and IB3 $(\rho=0.903$, $\mathrm{p}<0.01)$; RES2 and RES4 $(\rho=0.720, \mathrm{p}<0.01)$; IB2 and IB1 $(\rho=0.764, p<0.01)$, IB1 and IB4 $(\rho=0.721, p<0.01)$.

The analysis of the relationship between RES and independent variables shows that: (1) medium negative correlation exists in the case of IB; (2) most of the OC indicators are positively related to RES and (3) there are no statistically significant correlations with SN indicators. Stronger relationships were determined in the following dyads: RES1 and IB1 $(\rho=-0.408, p<0.01)$, RES3 and IB1 $(\rho=-0.458, p<0.01)$, RES3 and IB2 $(\rho=-0.435, p<0.01), \operatorname{RES} 1$ and IB3 $(\rho=-0.479$, $p<0.01)$, RES1 and IB4 $(\rho=-0.540, p<0.01)$, RES1 and OC1 $(\rho=0.323, p<0.01)$, RES1 and OC2 $(\rho=0.316, p<0.01)$, and

Table 5. Descriptive statistics and correlation coefficients

\begin{tabular}{|c|c|c|c|c|c|c|c|c|c|c|c|c|c|c|c|c|}
\hline & Mean & $\sigma$ & SN1 & SN2 & IB1 & IB2 & IB3 & IB4 & OC3 & OC9 & OC11 & oC15 & RES1 & RES2 & RES3 & RES4 \\
\hline SN1 & 4.494 & 1.697 & 1.000 & & & & & & & & & & & & & \\
\hline SN2 & 4.690 & 1.652 & $0.918^{*}$ & 1.000 & & & & & & & & & & & & \\
\hline IB1 & 5.908 & 1.326 & $0.248^{*}$ & $0.231^{*}$ & 1.000 & & & & & & & & & & & \\
\hline IB2 & 5.828 & 1.408 & 0.192 & $0.247^{*}$ & $0.764^{*}$ & 1.000 & & & & & & & & & & \\
\hline IB3 & 5.897 & 1.364 & $0.253^{*}$ & $0.233^{*}$ & $0.708^{*}$ & $0.614^{*}$ & 1.000 & & & & & & & & & \\
\hline IB4 & 5.920 & 1.305 & $0.244^{*}$ & $0.263^{*}$ & $0.721^{*}$ & $0.644^{*}$ & $0.903^{*}$ & 1.000 & & & & & & & & \\
\hline OC3 & 1.299 & 0.954 & -0.186 & -0.199 & $-0.281^{*}$ & $-0.247^{*}$ & ${ }^{*}-0.226^{*}$ & $-0.233^{*}$ & 1.000 & & & & & & & \\
\hline OC9 & 2.092 & 1.378 & $-0.318^{*}$ & $-0.227^{*}$ & ${ }^{*}-0.237^{*}$ & -0.154 & $-0.218^{*}$ & $-0.287^{*}$ & $0.448^{*}$ & 1.000 & & & & & & \\
\hline OC11 & 1.851 & 1.491 & -0.191 & -0.199 & -0.178 & -0.145 & -0.174 & -0.192 & $0.228^{*}$ & $0.414^{*}$ & 1.000 & & & & & \\
\hline OC15 & 1.253 & 0.852 & -0.168 & -0.117 & $-0.216^{*}$ & * -0.099 & -0.157 & $-0.222^{*}$ & $0.364^{*}$ & $0.237^{*}$ & $0.232^{*}$ & 1.000 & & & & \\
\hline RES1 & 2.195 & 1.429 & 0.051 & 0.006 & $-0.408^{*}$ & $-0.301^{*}$ & ${ }^{*}-0.479^{*}$ & $-0.540^{*}$ & $0.323^{*}$ & $0.316^{*}$ & $0.369^{*}$ & 0.207 & 1.000 & & & \\
\hline RES2 & 2.621 & 1.672 & -0.019 & 0.020 & $-0.372^{*}$ & $-0.305^{*}$ & ${ }^{*}-0.267^{*}$ & $-0.291^{*}$ & 0.123 & 0.172 & 0.098 & 0.084 & $0.596^{*}$ & 1.000 & & \\
\hline RES3 & 2.598 & 1.595 & 0.074 & 0.062 & $-0.457^{*}$ & ${ }^{*}-0.435^{*}$ & ${ }^{*}-0.372^{*}$ & $-0.368^{*}$ & 0.210 & 0.160 & 0.165 & 0.084 & $0.667^{*}$ & $0.836^{*}$ & 1.000 & \\
\hline RES4 & 2.299 & 1.593 & 0.065 & 0.075 & $-0.224^{*}$ & $-0.267^{*}$ & ${ }^{*}-0.360^{*}$ & $-0.335^{*}$ & $0.224^{*}$ & $0.231^{*}$ & $0.230^{*}$ & 0.064 & $0.566^{*}$ & $0.672^{*}$ & $0.720^{*}$ & 1.000 \\
\hline
\end{tabular}

Note: * p-value $<.01$

Source: Authors' calculations. 
RES1 and OC3 $(\rho=0.369, p<0.01)$. The results reveal that negative initial beliefs, low individual commitment and negative attitudes of reference groups (reflected in subjective norms) are positively related to resistance to BPM change.

\section{Assessment of model fit}

Hooper et al. (2008) propose the fit indices which have been used to conduct the assessment of model fit. The chi-square of the proposed conceptual model is 173.529 with 71 degrees of freedom. However, due to the sensitivity of chi-square with regards to the sample size, other indices have been used as well to assess the overall model fit, as shown in Table 6 .

The goodness-of-fit index (GFI) has been used in order to assess the correspondence between observed and hypothesized variance. For our model, the GFI is 0.801 , which could be considered as acceptable despite the recommendation that GFI should be higher than 0.90. Adjusted goodness-offit index (AFGI) for our model is 0.706, which could also be acceptable, although it is slightly low. The Normed-Fit index (NFI) and the Non-Normed-Fit index (NNFI) have also been calculated. For our model, they are close to 0.850, indicating a good fit (Bentler and Bonnet, 1980). Next, the Comparative-Fit Index (CFI) has been calculated, and even though it is slightly below 0.900 , it could also be considered acceptable. On the other hand, Root-mean-square-error (RMSEA) indicated close to satisfactory 0.127 values (e.g. Steiger, 2007). Looking at the results, our research model fulfilled the stated rigorous methodological requirements. This is a preliminary research, which is why we consider the values of the fitness indicators that are slightly below the threshold values as acceptable.

\section{Hypotheses testing}

The overall model revealed a good fit, so we could further investigate the structural part of the model. The main aim of this analysis is to estimate if the research hypotheses are empirically supported. The hypotheseses testing included the signs of the coefficients, their statistical significance, measured by t-value, and the amount of variance of endogenous constructs that is accounted for by independent constructs, measured by the multiple correlation coefficient squared $-R^{2}$.

Figure 2 presents the results of the path analysis. All of the hypotheses (H1, H2 and H3) were supported.

The first hypothesis (H1), suggesting that subjective norms are positively related to resistance to change, was accepted. The standard solution of path coefficient estimate from SN to RES was 0.393 with the t-value of 3.240 , which indicated the existence of a positive effect at $1 \%$ significance level. The second hypothesis (H2), indicating that initial beliefs are negatively related to resistance to changes, was accepted, with the standard solution of path coefficient estimate from IB to RES of -0.458 and t-value of -3.661 , which indicates the negative effect at $1 \%$ significance level Finally, the third hypothesis (H3), which explains the relation between the individual commitment toward organization and resistance to change, was accepted, with the standard solution of path coefficient estimate from OC to RES of 0.341 and t-value of 2.427, which indicates the existence of a positive effect at 5\% significance level. In addition, $\mathrm{R}^{2}$ value was 0.423 indicating that $42.3 \%$ of variations in RES could be explained by variations in SN, IB, and OC.

Table 6. Fit indices for the research model

\begin{tabular}{lcc} 
Fitness indicator & Model estimated & Explanations \\
\hline Chi-square $(\chi 2)$ & 173.529 & $\chi 2$ is not significant \\
\hline Degrees of freedom $(\mathrm{df})$ & 71 & \\
\hline$p$-value & 0.000 & Very good, close to 2 \\
\hline$\chi 2 / \mathrm{df}$ & 2.444 & Good result \\
\hline GFI & 0.801 & Fairly good result \\
\hline AGFI & 0.706 & Good result \\
\hline NFI & 0.824 & Good result \\
\hline NNFI & 0.853 & Good result \\
\hline CFI & 0.886 & close to 0.100, fairly good result \\
\hline RMSEA & 0.127 & Upper limit <.20, fairly good result \\
\hline $90 \%$ confidence interval of RMSEA & $(0.103 ; 0.152)$ &
\end{tabular}

Source: Authors' calculations. 
Figure 2. Path diagram with path coefficients estimates and their significance levels

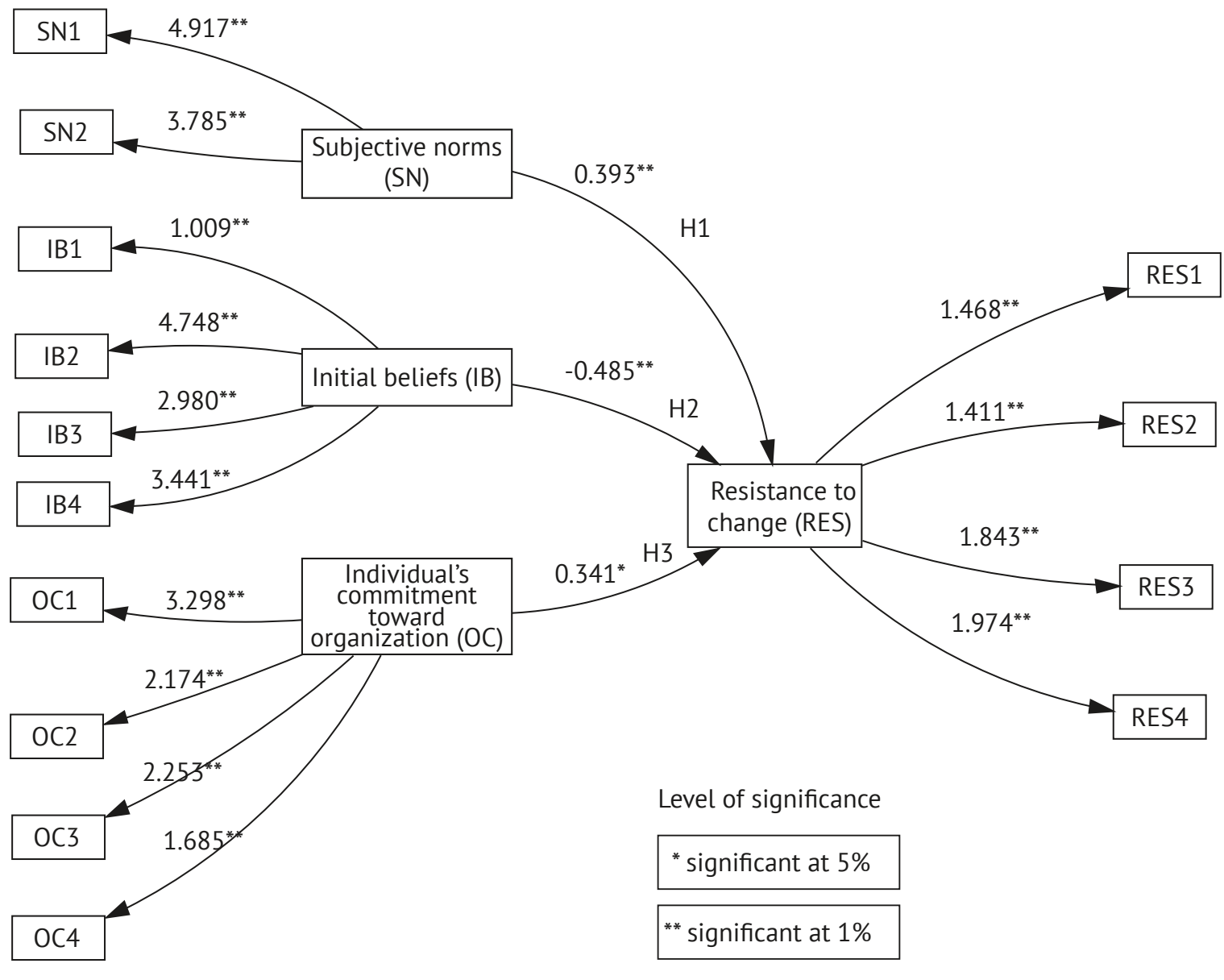

Source: Authors' calculations.

\section{Conclusions}

The research presented in this paper investigated the factors of employees' resistance toward BPM initiative in one insurance company. The research model included subjective norms, initial negative beliefs about BPM, and individual commitment towards organization as factors that increase the resistance to change. The results indicated that subjective norms and the individual commitment toward organization are positively related to the resistance to change, and the initial beliefs are negatively related to the resistance to change. These findings are in line with the previous research conducted by the authors Tennat and Wu (2005) and de Bruin and Doebeli (2009) about the negative attitudes regarding BPM.

Although we present the results of the preliminary research, our research findings are of great importance for both business practice and future research. Our research has tested the applicability of TRA in the field of resistance to change related to the introduction of BPM, and confirmed that the presumption that the individual's affinity for a particular behavior is determined by the individual's belief about the outcomes of that specific behavior, but also by the attitude of others, expressed by the subjective norms (Laumer et al., 2010). For the practitioners, we suggest that even more efforts should be devoted to the initial beliefs and social norms when a completely new BPM project is introduced or a significant change to the existing system is implemented. Very practical recommendations would include an application of an extensive educational program at the beginning of BMP implementation, as well as the identification of key opinion makers in organizations; the persons whose authority is not necessarily related to their formal positions, but stems from their expertise, especially in using technology.

While taking into account the results of our research, one should also have in mind the limitations. The first limitation of our work arises from the overall limitations of TRA, including "a risk of confounding attitudes and norms since attitudes can often be reframed as norms and vice versa and" (Ahmed et al., 2007), as well as "the assumption that when someone forms an intention to act, they will be free to act without limitation" (Ahmed et al., 2007). However, the others favor the use of TRA because of its origins in 
the research field of psychology (Laumer et al., 2010). Secondly, the paper presents the results of a preliminary research conducted in one insurance company, thus indicating that further research on a larger sample should be conducted in order to confirm the results of our analysis.

\section{Acknowledgment}

This paper is funded by the Croatian Science Foundation under the project PROSPER - Process and Business Intelligence for Business Excellence (IP-2014-09-3729).

\section{References}

Abdolvand, N., Albadvi, A., \& Ferdowsi, Z. (2008). Assesing readiness for business process reengineering. Business Process Management Journal, 14(4), 497-511. https://doi.org/10.1108/14637150810888046

Ahmad, H. F. A., \& Zairi, M. (2007). Business process reengineering: critical success factors in higher education. Business Process Management Journal, 13(3), 451-469. https://doi.org/10.1108/14637150710752344

Ahmed, H., Daim, T., \& Basoglu, N. (2007). Information technology diffusion in higher education. Technology in Society, 29(4), 469-482. https://doi.org/10.1016/j.techsoc.2007.08.011

Alibabaei, A., Aghdasi, M., Zarei, B., \& Stewart, G. (2010). The Role of Culture in Business Process Management Initiatives. Australian Journal of Basic and Applied Sciences, 4(7), 2143-2154.

Al-Mashari, M., \& Zairi, M. (2000). Revisting BPM: a holistic review of practice and development. Business Process Management Journal, 6(1), 10-42. https://doi.org/10.1108/14637150010283045

Aparecida da Silva, L., Martins Damian, I. P., \& Dallavalle de Pádua, S. I. (2012). Process management tasks and barriers: functional to processes approach. Business Process Management Journal, 18(5), 762-776. https://doi.org/10.1108/14637151211270144

Bentler, P. M., \& Bonnet, D. C. (1980). Significance tests and goodness of fit in the analysis of covariance structures. Psychological Bulletin, 88(3), 588-606. https://doi.org/10.1037/0033-2909.88.3.588

Bosilj Vuksic, V., Pejic Bach, \& M., Popovic, A. (2013). Supporting performance management with business process management and business intelligence: A case analysis of integration and orchestration. International Journal of Information Management, 33(2013), 613- 619. https://doi.org/10.1016/j.ijinfomgt.2013.03.008

Bosilj Vukšić, V., Pejić Bach, M., \& Suša Vugec, D. (2017). Understanding the Soft Side of BPM as a Competitiveness Driver: a Preliminary Research. In: E. Tomé, G. Neumann, \& B. Knežević (Eds.), Proceedings of the International Conference Theory and Applications in the Knowledge Economy Conference - TAKE 2017 (pp. 161-171).Zagreb, Croatia: Faculty of Business \& Economics.

Buh, B. (2016). Approaches towards business process management adoption under different organizational cultures, Doctoral dissertation. Ljubljana: University of Ljubljana, Faculty of Economics.

Buh, B., Kovacic, A., \& Indihar Stemberger, M. (2015). Critical success factors for different stages of business process management adoption - a case study. Economic Research-Ekonomska Istraživanja, 28(1), 243-258. https://doi.org/10.1080/1331677X.2015.1041776

Cameron, K. S., \& Quinn, R. E. (2006). Diagnosing and changing organizational culture: Based on the competing values framework. Reading, MA: Addison-Wesley.

Chiou, J. S. (1998). The effects of attitude, subjective norm, and perceived behavioral control on consumers' purchase intentions: The moderating effects of product knowledge and attention to social comparison information. Proceedings of the National Science Council, Republic of China. Part C, 9(2), 298-308.

Costello, A. B., \& Osborne, J. (2005). Best practices in exploratory factor analysis: four recommendations for getting the most from your analysis. Practical Assessment Research \& Evaluation, 10(7), 1-9.

de Bruin T., \& Doebeli G. (2009). Progressing an Organizational Approach to BPM: Integrating Experience from Industry and Research. In: E. Proper, F. Harmsen \& J. L. G. Dietz, (Eds.), Advances in Enterprise Engineering II. PRET 2009. Lecture Notes in Business Information Processing, Vol. 28 (pp. 34-49). Berlin, Heidelberg: Springer. https://doi.org/10.1007/978-3-642-01859-6_3

de Vaus, D. (2001). Research Design in Social Research. London, UK: Sage.

Decker, P. J., \& McCormack, C. (2008). Key Failure Factors: Interviews of Decision Strategists and Project Managers: A white paper. Houston, TX: Decision Strategies.

Decker, P., Durand, R., Mayfield, C. O., McCormack, C., Skinner, D., \& Perdue, G. (2012). Predicting implementation failure in organization change. Journal of Organizational Culture, Communications and Conflict, 16(2), 29-49.

Eikebrokk, T. R., Iden, J., Olsen, D. H., \& Opdahl, A. L. (2011). Understanding the determinants of business process modelling in organisations. Business Process Management Journal, 17(4), 639-662. https://doi.org/10.1108/14637151111149465

Faisal, M. N., \& Al-Esmael B. A. (2014). Modelling the enablers of organizational commitment. Business Process Management Journal, 20(1), 25-46. https://doi.org/10.1108/BPMJ-08-2012-0086

Feldt, L. S., \& Kim, S. (2008). A comparison of tests for equality of two or more independent alpha coefficients. Journal of Educational Measurement, 45(2), 179-93. https://doi.org/10.1111/j.1745-3984.2008.00059.x

Fishbein, M., \& Ajzen, I. (1975). Belief, attitude, intention and behavior: an introduction to theory and research. Reading, MA: Addison-Wesley.

Fjeldstad, Ø. D., \& Ketels, C. H. M. (2006). Competitive Advantage and the Value Network Configuration - Making Decisions at a Swedish Life Insurance Firm. Long Range Planning, 39(2), 109-131. https://doi.org/10.1016/j.lrp.2006.05.001 
Ford, J. D., Ford, L. W., \& D’Amelio, A. (2008). Resistance to change: the rest of the story. Academy of Management Review, 33(2), $362-377$. https://doi.org/10.5465/AMR.2008.31193235

Francischini, P. G., \& Mello, P. I. (2010). Identified Benefits of BPM Tools in Brazilian Insurance Companies. In: Proceedings of the 2010 POMS Annual Conference. Retrieved from https://www.pomsmeetings.org/ConfProceedings/015/FullPapers/015-0522.pdf

Goksoy, A., Ozsoy, B., \& Vayvay, O. (2012). Business Process Reengineering: Strategic Tool for Managing Organizational Change an Application in a Multinational Company. International Journal of Business and Management, 7(2), 89-112. https://doi.org/10.5539/ ijbm.v7n2p89

Hair, J. F., Black, W. C., Babin, B. J., Anderson, R. E., \& Tathan, R. L. (2006). Multivariate Data Analysis. Upper Saddle River, NJ: Prentice-Hall.

Hanafizadeh, P., \& Osouli, E. (2011). Process selection in re-engineering by measuring degree of change. Business Process Management Journal, 17(2), 284-310. https://doi.org/10.1108/14637151111122356

Harmon, E., Hensel, S., \& Lukes, T. (2006). Measuring performance in services. McKinsey Quarterly, 14(1), 31-39.

Haynes, S. N., Richard, D., \& Kubany, E. S. (1995). Content validity in psychological assessment: A functional approach to concepts and methods. Psychological assessment, 7(3), 238-247. https://doi.org/10.1037/1040-3590.7.3.238

Hofstede, G. (1993). Culture constraints in management theories. Academy of management executive, 7(1), 81-94.

Hooper, D., Coughlan, J., \& Mullen, M. R. (2008). Structural equation modelling: guidelines for determining model fit. Electronic Journal of Business Research Methods, 6(1), 53-60.

Hribar, B., \& Mendling, J. (2014). The correlation of organizational culture and success of BPM adoption. In: Proceedings of the 22nd European Conference on Information Systems (ECIS). Retrieved from http://aisel.aisnet.org/ecis2014/proceedings/track06/2/

Kettenbohrer, J. (2016). A Literature-Based Analysis of People's Roles in Business Process Management. In: Proceedings of the 22nd Americas Conference on Information Systems. Retrieved from http://aisel.aisnet.org/amcis2016/ITProj/Presentations/7/

Kettenbohrer, J., Eckhardt, A., \& Beimborn, D. (2015). A Theoretical Perspective on Meaningfulness of Work and the Success of Business Process Standardization Initiatives. In: Wirtschaftsinformatik Proceedings 2015, 37. Retrieved from http://aisel.aisnet.org/wi2015/37/

Kuo, Y. K. (2013). Organizational commitment in an intense competition environment. Industrial Management \& Data, 113(1), 39-56. https://doi.org/10.1108/02635571311289656

Laumer, S, Maier, C., \& Eckhardt, A. (2010). Why do they Resist? - An Empirical Analysis of an Individual's Personality Trait Resistance regarding the Adoption of New Information Systems. In: Proceedings of the European Conference on Information Systems, paper 31. Retrieved from http://aisel.aisnet.org/ecis2010/31

Laumer, S., \& Eckhardt, A. (2010). Why do People Reject Technologies? - Towards an Understanding of Resistance to IT-induced Organizational Change. In: Proceedings of the International Conference on Information Systems - ICIS, paper 151. Retrieved from http://aisel. aisnet.org/icis2010_submissions/151

Lin, H. F. (2007). Knowledge sharing and firm innovation capability: an empirical study. International Journal of manpower, 28(3/4), 315-332. https://doi.org/10.1108/01437720710755272

Lin, H. F., \& Lee, G. G. (2005). Impact of organizational learning and knowledge management factors on e-business adoption. Management Decision, 43(2), 171-188. https://doi.org/10.1108/00251740510581902

Mclvor, R., Humphreys, P., Mckittrick, A., \& Wall, T. (2009). Performance management and the outsourcing process: Lessons from a financial services organization. International Journal of Operations and Production Management, 29, 1025-1048. https://doi. org/10.1108/01443570910993474

Meyer, J. P., Stanley, L. J., \& Parfyonova, N. M. (2012). Employee commitment in context: the nature and implication of commitment profiles. Journal of Vocational Behavior, 80(1), 1-16. https://doi.org/10.1016/j.jvb.2011.07.002

Milanovic Glavan, Lj. (2011). Understanding process performance measurement systems. Business Systems Research, 2(2), 25-38. https:// doi.org/10.2478/v10305-012-0014-0

Palmer, B. (2004). Overcoming resistance to change. Quality Progress, 37(4), 35-40.

Pritchard, J. P., \& Armistead, C. (1999). Business process management - lessons from European business. Business Process Management Journal, 16(1), 15-37. https://doi.org/10.1108/14637159910249144

Recker,J. (2010). Continued use of process modeling grammars: the impact of individual difference factors. European Journal of Information Systems, 19, 76-92. https://doi.org/10.1057/ejis.2010.5

Rosemann, M., \& vom Brocke, J. (2010). The six core elements of business process management. In J. vom Brocke, \& M. Rosemann, (Eds.), Handbook on Business Process Management: Introduction, Methods and Information Systems, Vol. 1 (pp. 109-24). Berlin: Springer. https://doi.org/10.1007/978-3-642-00416-2_5

Schein, E. H. (1990). Organizational Culture. American Psychologist, 45(2), 109-119. https://doi.org/10.1037/0003-066X.45.2.109

Schmiedel, T., vom Brocke, J., \& Recker, J. (2013). Which cultural values matter to business process management? Results from a global Delphi study. Business Process Management Journal, 19(2), 292-317. https://doi.org/10.1108/14637151311308321

Sikdar, A., \& Payyazhi,J. (2014). A process model of managing organizational change during business process redesign. Business Process Management Journal, 20(6), 971-998. https://doi.org/10.1108/BPMJ-02-2013-0020

Steiger, J. H. (2007). Understanding the limitations of global fit assessment in structural equation modeling. Personality and Individual Differences, 42(5), 893-898. https://doi.org/10.1016/j.paid.2006.09.017

Tennant, C., \& Wu Y.C. (2005). Research and concepts - the application of business process reengineering in the UK. The TQM Magazine, 17(6), 537-545. https://doi.org/10.1108/09544780510627633 
Trkman, P. (2010). The critical success factors of business process management. International Journal of Information Management, 30(2), 125-134. https://doi.org/10.1016/j.ijinfomgt.2009.07.003

Tumbas, S., \& Schmiedel, T. (2013). Developing an Organizational Culture Supportive of Business Process Management. In: Wirtschaftsinformatik Proceedings 2013. Retrieved from http://aisel.aisnet.org/wi2013/115/

Van der Aalst, W. M. P. (2013). Business Process Management: A Comprehensive Survey. ISRN Software Engineering, 2013. Retrieved from http://dx.doi.org/10.1155/2013/507984

Van Looy, A., De Backer, M., \& Poels, G. (2014). A conceptual framework for classification of capability areas for business process maturity. Enterprise Information Systems, 8(2), 188-224. https://doi.org/10.1080/17517575.2012.688222

Vom Brocke, J., \& Sinnl, T. (2011). Culture in business process management: a literature review. Business Process Management Journal, 17(2), 357-377. https://doi.org/10.1108/14637151111122383

Vom Brocke, J., Schmiedel, T., Recker, J., Trkman, P., Mertens, W., \& Viaene, S. (2014). Ten principles of good business process management. Business Process Management Journal, 20(4), 530-548. https://doi.org/10.1108/BPMJ-06-2013-0074

Wong, A., Chau, P. Y. K., Scarbrough, H., \& Davison, R. (2005). Critical failure factors in ERP implementation. In: Proceedings of the Ninth Pacific-Asia Conference on Information Systems. Retrieved from http://aisel.aisnet.org/pacis2005/40/

Zhou, T., \& Li, H. (2014). Understanding mobile SNS continuance usage in China from the perspectives of social influence and privacy concern. Computers in Human Behavior, 37, 283-289. https://doi.org/10.1016/j.chb.2014.05.008

\section{Authors}

Mirjana Pejić Bach, PhD, is a Full Professor of System Dynamics, Managerial Simulation Games and Data Mining at the Department of Informatics, Faculty of Economics and Business, University of Zagreb. Her current research areas are simulation modeling, data mining and web content research. She is the (co) author of number of articles in international and national journals. She is actively engaged in number of scientific projects and collaborates in several applied projects in the field of data mining, simulation modeling and informatization.

Vesna Bosilj Vukšić, PhD, is a professor of Business Process Management, Knowledge Management and Business Computing at the Faculty of Economics and Business, University of Zagreb, at the Department of Informatics. Her current research interests are in business process and knowledge management.

Dalia Suša Vugec is a teaching and research assistant at the Department of Informatics, Faculty of Economics and Business, University of Zagreb, where she is also enrolled in a postgraduate doctoral study program. Her main research interests are BPM, organizational culture, unified communications, Web 2.0/3.0 technologies and digital literacy.

\section{Posameznikov odpor glede pobude menedžmenta poslovnega procesa: študija primera zavarovalnice}

\section{Izvleček}

Čeprav je posameznikov odpor zelo pogosto obravnavan kot ovira za uspeh menedžmenta poslovnega procesa, je literatura o tej temi redka.S ciljem razjasnitve tega področja smo izvedli raziskavo v hrvaški zavarovalnici.Z uporabo teorije utemeljenega dejanja smo testirali vpliv posameznikovega odpora glede pobude menedžmenta poslovnega procesa. Na osnovi podatkov, zbranih z anketiranjem zaposlenih v zavarovalnici, smo razvili model strukturne enačbe. Rezultati kažejo, da so subjektivne norme pozitivno povezane z odporom posameznika glede pobude menedžmenta poslovnega procesa, medtem ko začetno pozitivno prepričanje glede te pobude znižuje verjetnost odpora do spremembe.

Ključne besede: menedžment poslovnega procesa, teorija utemeljenega dejanja, posameznikov odpor, zavarovalnica, menedžment spremembe, Hrvaška 